\title{
Mudharabah As A Conduit For Social Cohesion Among Vulnerable Women
}

\author{
Fareiny Morni \\ Universiti Teknologi MARA \\ fareiny@yahoo.com
}

Azima Khan

INCEIF

\begin{tabular}{|ll|}
\hline Submitted & $: 11-07-2020$ \\
Accepted & $: 01-12-2020$ \\
Published & $: 29-12-2020$
\end{tabular}

\begin{abstract}
This research's focus is specified to the interlinkages between three concepts, i.e. social cohesion, women's economic empowerment, and mudharabah investments. Instead of microfinancing, this paper explores the possibility of utilizing mudharabah as a tool in uplifting vulnerable societies, especially women and promote social cohesion in the surrounding community. We explore the importance and value that empowering women economically can bring to improving society's cohesiveness and whether mudharabah can be used to achieve this. A case study method was used to highlight existing models used by NGOs to assist vulnerable women. However, existing models are limited to the funds available in the organization and turn; this restricts the aid that the NGO can give out. A mudharabah model would help NGOs outsource funding to individuals and institutions who can contribute capital to women and uplift them from their current economic condition. This paper proposes a two-tier mudharabah structure as an alternative financing model that can be used as a conduit for circulation and distribution of wealth in a society. This structure is financially viable and limits the capital providers' losses to the amount of their contribution.
\end{abstract}

Keywords: Mudharabah, Social Cohesion, Islamic Finance, Microfinancing

\section{A. Introduction}

As a financial instrument, mudharabah is widely used in the banking and capital market sector; namely as a tool in investment, fundraising and capital restructuring exercises. From a social viewpoint, however, the potential of mudharabah has not been fully explored. Microfinancing in the form of qardhasan has been considered one of the successful tools to alleviate and eradicate poverty as evidenced in Bangladesh, Bolivia, Sri Lanka, and Indonesia. However, the qardhasan model is unsustainable in the long run. Due to inflation and many other economic factors, the qardhasan fund's value will be eroded and depleted over time.

Social studies have always been concerned with the concepts of social cohesion, community and neighbourhood. The ties to the community through shared space, close kinship and shared religious and moral values are made more important and valuable in 
our present times. Moreover, these concerns also include poor people, many of them women and children, in disadvantaged parts of increasingly urbanized areas. These individuals suffer from the lack of opportunities, qualities, and elements necessary for creating and sustaining social cohesion.

The proliferation of crowdsourcing avenues has shown that if given the proper financing aid, women can uplift themselves out of their current financial situation and contribute to a country's economy. As a first step, we discuss the basics. We begin by defining and elaborating on social cohesion and economic empowerment of women. We examine how women can be empowered economically and whether this may affect social cohesion. We also propose a two-tier mudharabah model as a sustainable financing tool that social institutions can adopt as an alternative to the currently available microfinancing line of products.

This paper explores the potential of mudharabah as a tool to lift and empower vulnerable women and promote social cohesion.

\section{B. Literature Review}

\section{Vulnerable Women and Social Cohesion through Economic Empowerment}

Women face barriers in access to valued resources, including education, health, employment, access and ownership of land, banking and finance etc. Despite recent advances in essential aspects in girls and women's lives, pervasive challenges remain, most often due to widespread constraints. These constraints often violate women's most basic human rights.

Unequal access to resources and gender inequality has resulted in the death of about 100 million women in the developing world1(Sen, 1984, 1989, 1990, 1992, 2001). For women who are born, there is a lack of opportunities, rights, resources and voices. Looking at education, for example, even though the global gender gap had reduced from 19 per cent in 1980 to 11 per cent in 2010, low-income countries are still averaging less than five years for girls' schooling. Among the estimated 780 million illiterate adults worldwide, nearly two-thirds are women.

Women make financial decisions that impact the economy in different ways than men. They also tend to allocate more of their resources to family well-being and development. Therefore, it can be argued that empowering women can have broader positive economic effects on the community, including improved social cohesion. Increasing the value of women's time and their monetary income increases their bargaining or negotiating power. This results in greater participation in household decision-making. It also increases the funds spent on housing, feeding and educating children(Banerjee \& Duflo, 2000; Klasen \& Lamanna, 2009).

There is a bidirectional relationship between economic growth and women empowerment, which can improve women's health, education, rights and several other factors of development(Banerjee \& Duflo, 2011). Each of these factors is contributors to social cohesion. As a result of economic growth, for example, reducing poverty and

${ }^{1}$ Subsequent studies have revised the number of missing women to less or more than 100 million but the fundamental issue of women still stands, for example see Klasen \& Wink (2003). 
increasing opportunity may significantly impact gender equality. However, economic growth in western industrialized countries has not been able to remove gender inequality. Hence, economic growth on its own may not be enough. It may help but must be supplemented with other elements.

Some feminist economists view that women empowerment must be pursued as a goal on its own to achieve results(Banerjee \& Duflo, 2011). Another opinion states that economic development that conforms to existing patriarchal structures does not directly result in gender equality. Women's productive activities can contribute to economic growth if they are provided equal access to the necessary resources and opportunities. It also depends on improving policies at the state level, which facilitate broader participation of women in the paid workforce (Kabeer, 2016)

\section{Mudharabah and Social Cohesion}

According to Islam, an individual cannot exist without society (Fazlur Rahman, 1980). The Quran states that societies fall into decay due to the neglect that they have cast in by their prosperous members $(89: 15-20)$. There is an emphasis given to strengthen the weaker sections of society, including the poor, orphans, women, slaves, and those in debt. The rich should spend certain portions of their wealth towards the welfare and improvement of the poor and the needy. The mechanisms of sadaqah, zakat, waqf and trade are all aimed at the Muslim collective society; the Ummah. Therefore, it can be said that with the focus on uniting the society and the circulation of wealth through the methods mentioned above, Islam provides well-known and established methods that have social cohesion as a basis.

Muslim women's rights in today's world is a complex issue. As per Al-Hibri(2001), progress on this topic can be harmed if Muslim women's unique topology and unique cultural and spiritual authenticity are not understood. Women's rights are affected by misleading cultural assumptions which are different from religious ones. Therefore Muslim women living in western countries face fewer obstacles when it comes to empowerment and legal rights than the rest of the world (Al-Hibri, 2001).

Essentially, mudharabah is "a partnership contract between the capital provider (rabb al-m $\llbracket$ l) and an entrepreneur (mulh $[\mathrm{rib}$ ) whereby the capital provider would contribute capital to an enterprise or activity that is to be managed by the entrepreneur. Profits generated by that enterprise or activity are shared following the percentage specified in the contract, while losses are to be borne solely by the capital provider unless the losses are due to misconduct, negligence or breach of contracted terms". Both the involved parties take on a portion of the risk to share in a mutually agreed and contribution-based, fair manner and not borne by just one of them(Ul Haque \& Mirakhor, 1986).

The creation of various crowdsourcing platforms such as Kickstarter, Indiegogo, Kiva, gofundme and many others have demonstrated an opportunity for alternative forms of financing. In the Islamic finance spectrum, organizations such as EthisCrowd help pave the way towards Shari'ah-compliant crowdfunding based on the mudharabah structure. The 
crowd funders/ investors provide payments directly to project owners, and from there, construction work is carried out. Islamic banks provide partial construction financing for the units. As the units are completed, they are submitted to the Islamic banks in batches. Each completed unit is paid for in full by the bank. Profits realized are shared and paid out to investors.

It can be argued that similar focus can be applied to enabling women specifically through structured Islamic financial instruments. This promotes economic growth which takes into account the heterogeneity and particular characteristics of women. Women who have been able to progress in their chosen fields and have become successful can serve as success stories. These women can work as role models, mentors and investors for women entrepreneurs held back only by a lack of financing or experience. In the next section, we provide an overview of two organizations working towards such goals.

\section{Case Study: Behbud Association, Pakistan and Helping Hands Penan, Malaysia}

This section looks at two (2) separate organizations that were established with the same objective, i.e., empowering vulnerable women and uplifting them out of their current economic condition. Both organizations are currently operating in two (2) different countries; (1) Behbud Association Pakistan and (2) Helping Hands Penan in Malaysia.

\section{a. Behbud Association, Pakistan}

Behbud Association Pakistan (Behbud) was established as a volunteer group in 1967 to empower women and their surrounding communities. This is achieved by providing the women with access to education opportunities, healthcare facilities, incomegeneration activities, and vocational training that would enable vulnerable women to uplift themselves (and their family) from their current situation.

The institution assists vulnerable women in many ways, including providing interest-free micro lending to poor women and the staff of Behbud in the form of scholarships to deserving students, funds for income generating purposes, and medicines to the poor.

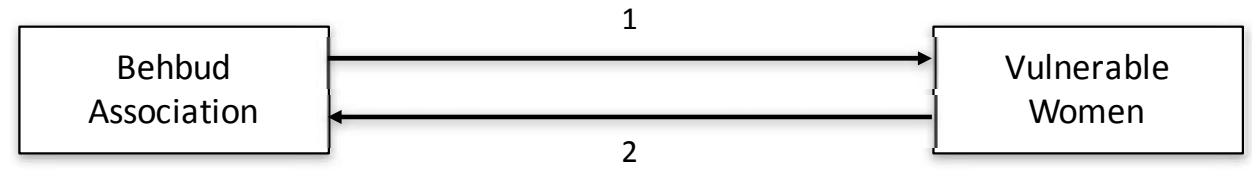

Figure 1 The Interest-Free Micro-Credit lending employed by Behbud Association Pakistan.

The interest-free micro-credit lending is given in qardhasan (benevolent loan), and the process can be seen in

Figure 1 above. 
1. Firstly, the association identifies individuals who require funds. These individuals could also approach the association and apply for funding. The association then evaluates the individual's situation, assesses the amount approved for funding, and discusses the borrower's repayment schedule. The funds are disbursed to the borrower as agreed between Behbud and the borrower.

2. The borrower repays the funds following the pre-agreed repayment schedule.

\section{b. Helping Hands Penan, Malaysia}

Helping Hands Penan (HHP) is a non-government organization (NGO) established in 2008 by a group of women who got together intending to help the Penan. This nomadic tribe lives in the heart of Sarawak, Malaysia.

Through various settlement schemes, the Penan tribe receives monetary and nonmonetary assistance from the government and several government-linked institutions to help them build a new life in their new settlements areas. However, the aid received by the Penans is not enough for them to meet their daily expenses hence it is not unusual for the younger members of the tribe to drop out from school as they are needed by their family to work the land or gather food from the forest.

HHP was established to empower Penan women to help themselves and their family. The organization capitalized on Penan women's talent who are well-known for their ability to weave rattan, bamboo and various other materials into rugs, bags and baskets. HHP buys the goods from Penan women and then sells them to public members as souvenirs and everyday items by supplying the goods to retailers and setting up pop-up booths at weekend markets. The raised funds are channelled back to the Penan community, specifically those within the Ulu Limbang and Ulu Baram settlement areas. With the funds, the Penan community are expected to fund their children to school and later send their kids to university.

2

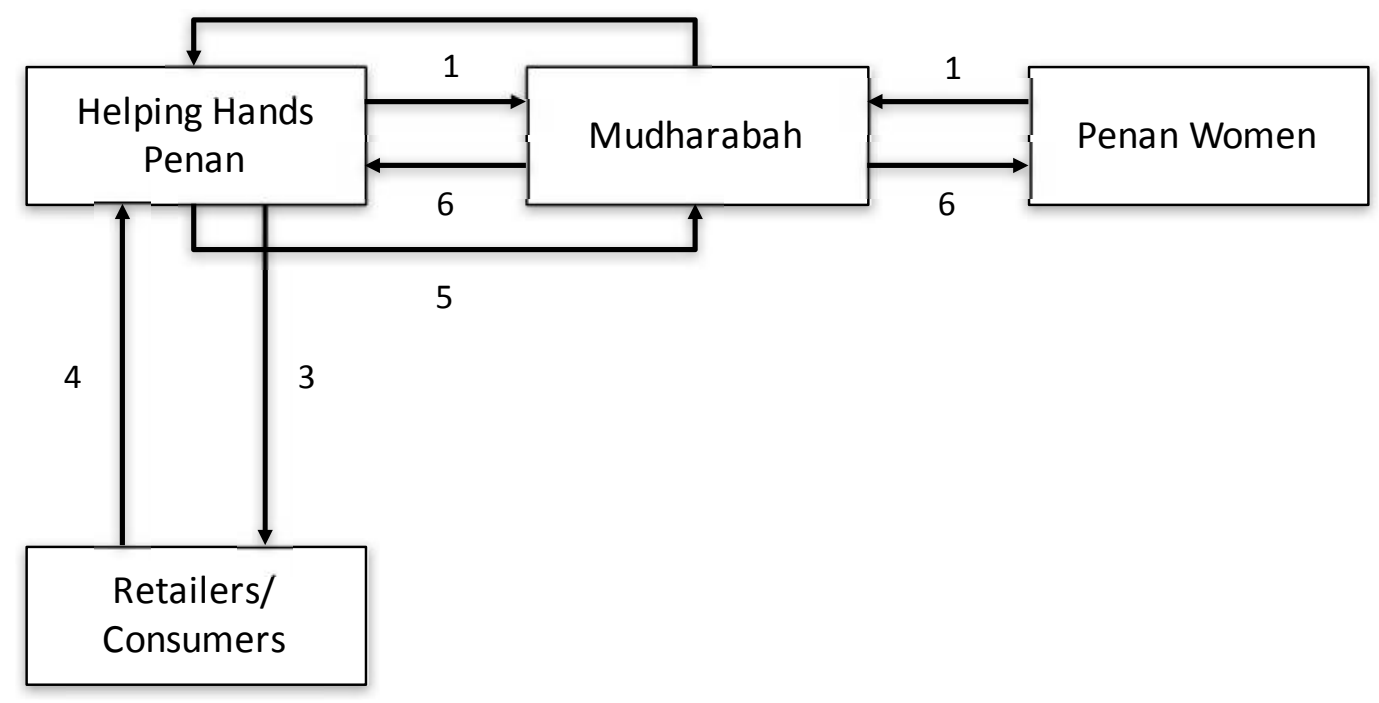




\section{Figure 2 The Modified Mudharabah Structure employed by Helping Hands Penan}

The business model employed by HHP appears to follow a two-tier mudharabah structure:

1. The Helping Hands Penan (HHP) enters into a mudharabah arrangement with women of the Penan tribe where the HHP acts as the mudharib (entrepreneur) who will sell the goods made by the Penan women. The Penan women act as the rabbul-mal (capital provider) and contribute their finished goods to the venture.

2. HHP supplies the bags to retailers and sells the bags themselves in various weekend markets and charitable bazaars regularly organized throughout Malaysia. They employ volunteers to sell the goods to reduce their operating costs and maximize the returns, which will be channelled back to the Penan weavers.

3. The goods are sold to retailers and consumers.

4. Proceeds from retailers and through the weekend markets are channelled back to HHP.

5. HHP ploughs back the proceeds into the mudharabah arrangement, where the capital is reused to buy more materials for the Penan women to weave into bags, rugs, and baskets to be sold in the future.

6. Profits made from the venture are distributed between HHP and the Penan weavers based on a pre-agreed profit-sharing ratio.

It must be noted that HHP provides the initial capital i.e. the raw materials used to weave the rugs, baskets and bags at the beginning of the partnership. However, as time progressed, the sale proceeds are used to purchase more materials. Since the inception of HHP, the organization have made a positive impact to the lives of Penan women: (1) the business activities from making rugs, baskets and bags have provided the Penan women with a permanent source of income; (2) the Penan tribe in the Ulu Limbang and Ulu Baram settlement areas who participated in HHP's activities are less dependent on government aid and are more economically empowered; and (3) there has been a significant reduction in the number of dropouts among the Penan children in the Ulu Limbang and Ulu Baram settlement areas.

Because HHP operates on a small scale, the organization's positive impact is found to affect only a limited number of Penan women, i.e. only those in the Ulu Limbang and Ulu Baram settlement areas. The mudharabah business model employed by the organization is found to be sustainable; the organization have been able to sustain its operation for the past nine (9) years while at the same time providing sufficient income to both HHP and the Penan communities.

\section{Discussion}

\section{Proposed Mudharabah Social Financing Model}

Building on the foundations of the classical mudarabah contract and the success of HHP, we propose a two-tiered mudarabah model which would effectively channel funds from investors to vulnerable societies. These funds would be more extensive than what the NGO could have provided if they depended solely on their fundraising activities. 


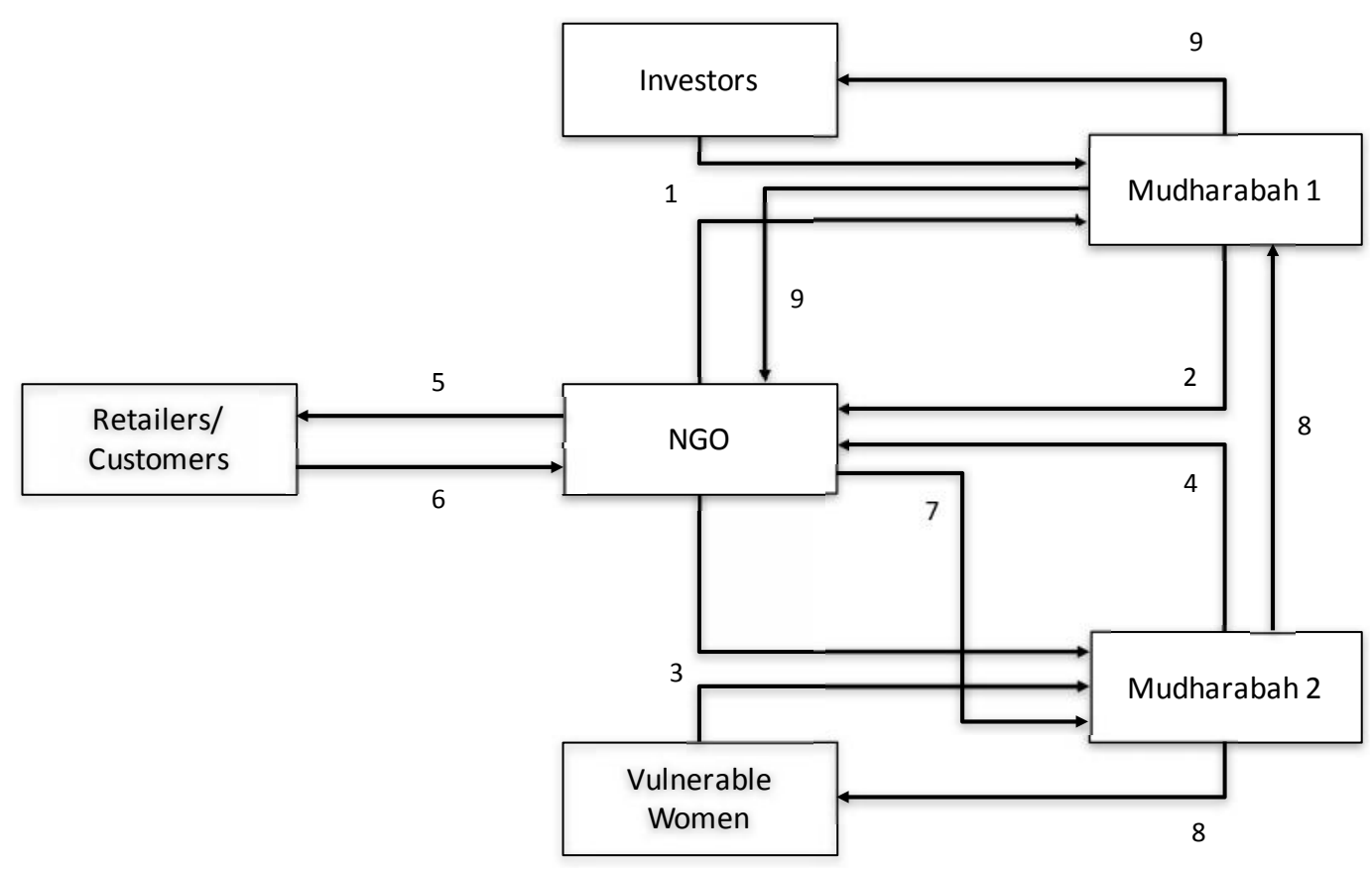

Figure 3 Two-tier Mudharabah Model

The operationalization of the two-tier mudharabah structure:

1. The investors and the NGO enter into a mudharabah contract, where the investors are the capital (rabbul-mal) provider and the NGO is the entrepreneur (mudharib).

2. The funds from the first mudharabah structure are transferred into the NGO, to be channelled to productive activities to help vulnerable women.

3. The NGO then enters into a second mudharabah contract with a group of vulnerable women. The NGO is the provider of funds (rabbul-mal), and the vulnerable women are the entrepreneur (mudharib). In this structure, the NGO provides much-needed capital to a group of vulnerable women to finance productive and economically viable activities. The women utilize the funds as seed money or capital and uses it to produce various goods.

4. The NGO takes the goods that were produced by the women and acts as the wakeel or representative to the vulnerable women, supplying the goods to retailers and consumers.

5. The NGO then sells the goods through retailers or on their own at weekend markets, charity bazaars or even online.

6. The NGO collects sale proceeds from retailers and customers.

7. Profit from the sales is channelled back into the second mudharabah contract between the $\mathrm{NGO}$ and the vulnerable women.

8. Profits are distributed based on a pre-agreed profit-sharing ratio. The profits that are due to the vulnerable women are rightly transferred to the women while the profits that are due to the NGO are channelled into the first mudharabah contract.

9. The profits are divided based on the pre-agreed profit-sharing ratio between the investors and the NGO. 
This model is simulated onto an Excel worksheet to determine the project's viability and calculate the potential returns or any losses that may be incurred by the investors. Assuming that:

1. The investors each contribute MYR 100 into the seed fund;

2. There are 100 investors;

3. Each good cost MYR 20 to make;

4. The goods can be sold for MYR 50 each;

5. Selling and administration costs are at 20 per cent of sales;

6. The profit-sharing ratio of the second mudharabah contract between the NGO and the vulnerable women is at equal percentages (50: 50 each) and;

7. The first mudharabah contract's profit-sharing ratio is 30: 70 for the NGO and investors, respectively.

The following table shows the potential returns or any losses incurred by investors, should the project be able to sell at 100 per cent, 75 per cent and 50 per cent respectively.

Table 1 Simulated Returns for the Proposed Two-Tier Mudharabah Structure

\begin{tabular}{|c|c|c|c|}
\hline \multicolumn{3}{|c|}{ Capital contributed by investors (individually) } & MYR 100 \\
\hline \multicolumn{3}{|l|}{ No. of investors } & 100 \\
\hline \multicolumn{3}{|l|}{ Total capital provided by investors } & MYR 10,000 \\
\hline \multicolumn{3}{|l|}{ Cost of goods (per unit) } & MYR 20 \\
\hline \multicolumn{3}{|l|}{ No. of goods produced $^{2}$} & 500 units \\
\hline \multicolumn{3}{|l|}{ Selling price per unit } & MYR 50 \\
\hline \multirow[t]{2}{*}{ Sales capacity at: } & 100 per cent & 75 per cent & 50 per cent \\
\hline & MYR & MYR & MYR \\
\hline Sales & 25,000 & 18,750 & 12,500 \\
\hline (-) COGS & $(10,000)$ & $(10,000)$ & $(10,000)$ \\
\hline Gross Profit & 15,000 & 8,750 & 2,500 \\
\hline (-) Selling \& Admin Costs, $20 \%$ & $(5,000)$ & $(3,750)$ & $(2,500)$ \\
\hline Net Profit & 10,000 & 5,000 & 0 \\
\hline Profit to $2^{\text {nd }}$ Mudharabah Contract & 10,000 & 5,000 & 0 \\
\hline Profit to vulnerable women, $50 \%$ & 5,000 & 2,500 & 0 \\
\hline Profit to $1^{\text {st }}$ Mudharabah Contract & 5,000 & 2,500 & 0 \\
\hline
\end{tabular}

${ }^{2}$ No of good produced are calculated as capital provided by investors divided by cost of goods (per unit). 


\begin{tabular}{|l|c|c|c|}
\hline Profit received by investors, 70\% & 3,500 & 1,750 & 0 \\
\hline Profit received by NGO & 1,500 & 750 & 0 \\
\hline \multicolumn{3}{|l|}{} \\
\hline Return per investor (\%) & 35 & 17.5 & 0 \\
\hline
\end{tabular}

From the simulated income statement, it can be seen that, with a 100 per cent sales, the group of vulnerable women would benefit from a slightly higher return compare to the mudharabah investors. The return received by the investors would be at 35 per cent of their invested capital of MYR 100, which is higher compared to current Sukuk returns and is comparable to returns from investing in the stock market.

At 75 per cent sales, the group of vulnerable women would also be entitled to a slightly higher return than the mudharabah investors. However, it should be noted that the returns received by the mudharabah investors, at 17.5 per cent per invested capital of MYR 100 , are still higher than current returns in the sukuk market and comparable to returns in the stock market.

At 50 per cent sales, all three (3) parties, i.e. the vulnerable women, NGO and mudharabah investors would not be entitled to any share in profits, because there are no profits derived from the partnership. Nevertheless, it should be noted that the sales returns are enough to cover all the costs involved in the mudharabah arrangement. Hence, despite not deriving any profits, the mudharabah investors do not lose their invested capital in the mudharabah contract. The revenue is enough to cover all expenses incurred in the contract.

\section{Conclussion}

Both Behbud and HHP are examples where empowering vulnerable women can make a positive impact on society. Both institutions enhance social cohesion in the community and financially elevate the community's well-being as women become more financially capable of securing their income. These women can improve the financial condition of their family and contribute productively towards society.

The mudharabah contract structure is a sustainable financing structure that could be adopted by NGOs and charitable institutions to provide sustainable funding to communities that are in need. The structure has two (2) distinct advantages: first, it limits the exposure faced by the mudharabah investors to their capital investments only; and secondly, because of the way the contract is designed, mudharabah investors, have the opportunity to earn returns that are comparable to equity products and with a limited downside loss that is limited to the capital contributed by the investors.

The business model introduced by HHP stands as an example of how women are working together to empower other women. Given the right tools and opportunity, women can financially contribute to their household income and assist their family to come out of their vulnerable situation. 


\section{Bibliography}

Al-Hibri, A. (2001). Muslim women's rights in the global village: Challenges and opportunities. Journal of Law and Religion.

Banerjee, A. V, \& Duflo, E. (2000). Inequality and growth. National Bureau of Economic Research.

Banerjee, A. V, \& Duflo, E. (2011). Poor economics: A radical rethinking of the way to fight global poverty. Public Affairs.

Behbud Association Pakistan. (n.d.). Our Story. Retrieved December 29, 2017, from http://behbud.org/our-story/

Fazlur Rahman. (1980). Major Themes of the Quran. Chicago: The University of Chicago Press.

Helping Hands Penan. (n.d.). About. Retrieved December 29, 2017, from https://web.facebook.com/pg/HHPenan/about/?ref=page_internal

Kabeer, N. (2016). Gender equality, economic growth, and women's agency: the "endless variety" and "monotonous similarity" of patriarchal constraints. Feminist Economics, 22(1), 295-321.

Klasen, S., \& Lamanna, F. (2009). The Impact of Gender Inequality in Education and Employment on Economic Growth: New Evidence for a Panel of Countries. Feminist Economics, 15(3), 91-132. https://doi.org/10.1080/13545700902893106

Klasen, S., \& Wink, C. (2003). "Missing women": Revisiting the debate. Feminist Economics, 9(2-3), 263-299.

Sen, A. (1984). Economic Development: Some Strategic Issues. Asian Journal of Economics and Social Studies, 3.

Sen, A. (1989). Women's Survival as a Development Problem. Bulletin of the American Academy of Arts and Sciences, November.

Sen, A. (1990). More than 100 million women are missing. The New York Review of Books.

Sen, A. (1992). Missing women. British Medical Journal, 304(6827), 587-588. https://doi.org/10.1136/bmj.304.6827.587

Sen, A. (2001). The many faces of gender inequality. New Republic.

Ul Haque, N., \& Mirakhor, A. (1986, November). Optimal Profit-Sharing Contracts and Investment in an Interest-Free Islamic Economy. 